\title{
PHYSIOLOGICAL QUALITY SEEDS OF Clitoria fairchildiana R. A. HOWARD DURING STORAGE
}

\author{
QUALIDADE FISIOLÓGICA DE SEMENTES DE Clitoria fairchildiana R. A. \\ HOWARD DURANTE O ARMAZENAMENTO
}

\author{
Magnólia Martins ALVES ${ }^{1}$; Edna Ursulino ALVES ${ }^{2}$; Sueli da Silva SANTOS-MOURA ${ }^{3}$ \\ 1. Mestranda de Agronomia, Departamento de Fitotecnia e Ciências Ambientais, CCA, Universidade Federal da Paraíba - UFPB, Areia, \\ PB, Brasil; 2. Professora, Doutora, Departamento de Fitotecnia e Ciências Ambientais - CCA - UFPB, Areia, PB, Brasil. \\ ednaursulino@cca.ufpb.br; 3. Doutoranda em Agronomia, Departamento de Fitotecnia e Ciências Ambientais, CCA - UFPB, Areia, PB, \\ Brasil.
}

\begin{abstract}
The species Clitoria fairchildiana R. A. Howard, belonging to the family Fabaceae is a fastgrowing ornamental tree, with potential for use in reforestation for heterogeneous vegetation reconstruction and recovery of degraded areas. Storage is aid in quality programs, which allows the preservation of the quality of seeds, however, the water content of the same is a crucial factor in its preservation, because it is high may cause deterioration and death of seeds stored. In this way the objective to evaluate the germination and vigor of seeds of $C$. fairchildiana stored with different levels of water. That's way was an experiment in completely randomized design in a factorial $5 \times 7$ (water levels and periods of storage). Before storage for 20, 40, 60, 80, 100 and 120 days, the seeds were subjected to drying in an oven at $40{ }^{\circ} \mathrm{C}$ for $0,6,12,18$ and $12: 0 \mathrm{am}$, to obtain the following water levels: $\mathrm{TA}_{1}=19.05, \mathrm{TA}_{2}=13.60, \mathrm{TA}_{3}=11.99 \%, \mathrm{TA}_{4}$ $=10.51 \%$ and $\mathrm{TA}_{5}=8.70 \%$, respectively. After each interval of storing seeds were subjected to the following evaluations: determination of the moisture content, germination and vigor tests (emergency, first count of germination and emergence and germination speed index and emergence, seedling dry mass and length). The reduction of water content of seed $C$. fairchildiana to 10.5 and $8.7 \%\left(\mathrm{TA}_{4} \mathrm{TA}_{5}\right.$ and, respectively) resulted in greater preservation during storage, giving Orthodox behavior for stand drying until it reaches the water content of around $8 \%$.
\end{abstract}

KEYWORDS: Longevity. Vigor. Forest species.

\section{INTRODUCTION}

The species Clitoria fairchildiana R. A. Howard, better known as sombreiro is a native of the Amazon forest, belonging to the family Fabaceae, whose wood is used in construction as internal partitions, ceilings, manufacturing of toys and boxing; its growth is fast, so is widely used in afforestation, reforestation programs permanent preservation and heterogeneous the fruits of that species is a pod that must be harvested directly in the tree at the beginning of the natural sun-dried and dehiscence to complete the opening and release of seed (LORENZI, 2009).

For a variety of native forest species have irregular seed production, being abundant in given year and insufficient in others, so the storage becomes necessary to ensure the annual demand of seeds for the production of seedlings that may be employed in reforestation programs, as well as, allow the stock for years in which seed production is low (CARNEIRO; AGUIAR, 1993). However, studies on the behavior of seeds during the storage period and the availability of information on technologies that promote greater still are inadequate, making it difficult to use properly.
With regard to storage, the same is a technique that can be used to preserve the quality of seed and make them available in different times of the year, however, some factors must be observed, such as the water content of the seeds, used packaging and environmental features such as temperature and relative humidity, in order to ensure the maintenance of the germination and vigor of seeds during this process (CARVALHO; NAKAGAWA, 2012).

Among the techniques to promote better conditions for greater conservation of seed in storage, reducing your metabolism, by decreasing the water content of the seeds is the most used (ALVES et al., 2008). Thus, prior knowledge of the physiological behavior of seed during drying and storage is of paramount importance, since not all seeds are desiccation tolerant, requiring special conditions in the realization of these procedures for their effective conservation.

How much tolerance to desiccation, the seeds are classified into two distinct groups, the Orthodox remain viable after drying the water content below 5\% and long periods of storage in low temperature conditions, while quickly loses viability if recalcitrant are dried to very low water levels (ROBERTS, 1973). There's still the seeds 
with intermediate behavior, tolerating the desiccation around 10\% water, but do not support low temperatures for prolonged periods of time, as verified by (CARVALHO et al., 2006) in several forest species.

In this way, the maintenance of seed in storage depends on many factors, among them, the water content is of paramount importance, as it has influence over the storage potential of the same, since if high consumption increases reserves by breathing and consequently the degeneration and the proliferation of micro-organisms, reducing germination and vigor (CARVALHO; NAKAGAWA, 2012), thus, the knowledge of the ideal water content of seed of a species, as well as its dehydration tolerance is critical to the conservation of these during storage.

Given the above, the objective of this work was to evaluate the germination and vigor of seeds of $C$. fairchildiana stored with different levels of water.

\section{MATERIAL AND METHODS}

The experiment was conducted in the laboratory of seed Analysis (LAS) from the Centro de Ciências Agrárias, of Universidade Federal of Paraíba (CCA-UFPB), in the municipality of Sand PB, with Clitoria fairclildiana seeds obtained from fruits collected in selected trees in that city when it began the dispersal and natural dehiscence. After collecting the fruits were taken to LAS where were debulhados manually to remove the seeds, which were homogenized and separated into lots to obtain the different levels of water through drying.

The seeds were subjected to drying in an oven set at $40{ }^{\circ} \mathrm{C}$ for $0,6,12,18$ and 12:0 am in order to obtain the different water levels: $\mathrm{TA}_{1}=$ 19.05, $\mathrm{TA}_{2}=13.60, \mathrm{TA}_{3}=11.99, \mathrm{TA}_{4}=10.51$ and $\mathrm{TA}_{5}=8.70$, respectively, and the period (zero) constituted the witness, whose seeds were stored with the initial water content. After each drying period of seed samples were removed from the oven, which were placed in Kraft paper bag and stored in the fridge $\left(6 \pm 2^{\circ} \mathrm{C}\right.$ and $\left.38 \% \pm 3 \mathrm{UR}\right)$ for up to 120 days, with evaluations in the intervals of $0,20,40,60,80,100$ and 120 days, and after each period seeds were subjected to the following evaluations:

\section{Determination of water content}

Content of the seeds was determined before and after each period of drying and storage, in four sub-amostras of 10 seeds for each treatment, using the method of oven at $105 \pm 3^{\circ} \mathrm{C}$ for 12:0 am, following the recommendations of Brasil (2009), with the results expressed in percentage.

\section{Germination test and emergency}

After each period of storage, four replicates of 25 seeds for the different levels of water and treated with the fungicide Captan on concentration of $240 \mathrm{~g} 100 \mathrm{~kg}-1$ of seed were distributed on two sheets of paper towels, covered with a third, all moistened with distilled in quantity equivalent to 3.0 times its dry mass and organized in the form of rollsthen they were put in plastic bags to prevent water loss by evaporation. The germination test was conducted in a Germinator Biochemical Oxygen Demand type (B.O.D.) set in constant temperature of $30^{\circ} \mathrm{C}$, being the evaluations carried out from 9 to 21 days after installing the test, adopting as a criterion for the assessment of normal seedlings (root and shoot perfect) as recommendation of (BRASIL, 2009).

For the emergency test four replicates of each treatment 25 sementes were sown with the hilum facedown in plastic trays $(49 \times 33 \times 7 \mathrm{~cm}$ of length, width and thickness, respectively), containing sand washed and sterilized in autoclave at $120^{\circ} \mathrm{C}$ as substrate. The test was conducted in a greenhouse without temperature and humidity control and damping held once a day with sufficient quantity to keep the damp substrate; the evaluations of the number of emerged seedlings were made daily, from 9 to 21 days with the results expressed in percentage.

\section{First count of germination and emergence}

The first count of germination and emergence was effected in conjunction with the tests of twinning and emergency, computing the percentage of normal seedlings obtained at nine days after the installation of the germination tests and emergency, respectively, whose results were expressed as percentage.

\section{Germination speed index (IVG) and emergency (IVE)}

For these tests were performed daily counts of normal seedlings, at the same time, the nine to twenty days after sowing to germination test and 9 to 21 days for emergency testing, the index was calculated using the formula proposed by (MAGUIRE, 1962).

\section{Length and dry mass of root and shoot of seedlings}

At the end of the experiments, the normal seedlings of each treatment and repetition were 
measured (primary root and aerial part) with the help of a ruler graduated in centimeters and the results expressed as inches per seedling-1. After the measurements, the same seedlings were separated into roots and aerial parts and placed in Kraft paper bags; then were placed to dry in an oven set at $80^{\circ} \mathrm{C}$ for 12:0 am, with the results expressed in $\mathrm{g}$ seedling-1.

\section{Experimental design and statistical analysis the experimental}

Design was completely randomized, with treatments distributed in $5 \times 7$ factorial scheme (water levels and periods of storage), in four repetitions of 25 seeds per treatment; the data were subjected to analysis of variance and polynomial regression, linear and quadratic models testing.

\section{RESULTS AND E DISCUSSION}

Throughout the store there was reduction in seed moisture, being more pronounced in those in which the initial moisture was higher, probably because they have not reached the hygroscopic equilibrium (Figure 1).

The percentage of germination (Figure 2A) of seeds stored with $19.05\left(\mathrm{TA}_{1}\right)$ and $13.60 \%\left(\mathrm{TA}_{2}\right)$ decreased throughout the store, with greater reductions in seeds with higher humidity, which lost their viability to 80 days of storage, while the data for the seeds with water levels $11.99\left(\mathrm{TA}_{3}\right), 10.51$ $\left(\mathrm{TA}_{4}\right)$ and $8.70 \%\left(\mathrm{TA}_{5}\right)$ does not set the polynomial regression models, obtaining mean values of 72,75 and $71 \%$ of germination, respectively.

The percentage of emergency (Figure 2B) of seedlings from seeds stored with $19.05 \%$ water content $\left(\mathrm{TA}_{5}\right)$ reduced to values close to $5 \%$ for 100 days. Regarding the seeds with water levels of 13.60 $\left(\mathrm{TA}_{2}\right)$ and $8.70 \%\left(\mathrm{TA}_{5}\right)$ there was no storage periods influences on the emergence of seedlings, whose average percentages were 67 and $70 \%$, respectively. On the other hand, for the seeds stored with water levels of $11.99\left(\mathrm{TA}_{3}\right)$ and $10.51 \%\left(\mathrm{TA}_{4}\right)$, the emergence decreased linearly along the storage (Figure 2B).

The data from the first count of germination (Figure 2C) if found that the vigor of seeds of $C$. fairchildiana with $19.05 \%$ water content $\left(\mathrm{TA}_{1}\right)$ decreased throughout the store, demonstrating behavior similar to that observed in germinating end, however, for the water content of $13.60 \%$ $\left(\mathrm{TA}_{2}\right)$ to 25 days maximum germination obtained was $62 \%$, whereas with $11.99 \%\left(\mathrm{TA}_{3}\right)$, the highest percentage of germination in the first count $(70 \%)$ was observed for 45 days of storage. When the water content was $10.51 \%\left(\mathrm{TA}_{4}\right)$ at 44 days found $78 \%$ germination on the occasion of the first count and to $8.70 \%$ humidity $\left(\mathrm{TA}_{5}\right)$ with 55 days was obtained the largest percentage $(78 \%)$ of germination in the first count.

For the first count of emergence of seedlings of $C$. fairchildiana quadratic effect was verified data obtained from stored seeds with water levels of $11.99\left(\mathrm{TA}_{3}\right)$ and $10.51 \%\left(\mathrm{TA}_{4}\right)$, whose highest values (56 and 61\%) were obtained at the age of 54 and 62 days of storage, respectively. For contents of water from $13.60\left(\mathrm{TA}_{2}\right)$ and $8.70 \%$ $\left(\mathrm{TA}_{5}\right)$ data set the polynomial regression models, with averages of 42 and $39 \%$ of emergency on first count, respectively, while for the water content of $19.05 \%\left(\mathrm{TA}_{1}\right)$ there was across-the-board reduction of emergence of seedlings with increased storage time (Figure 2D).

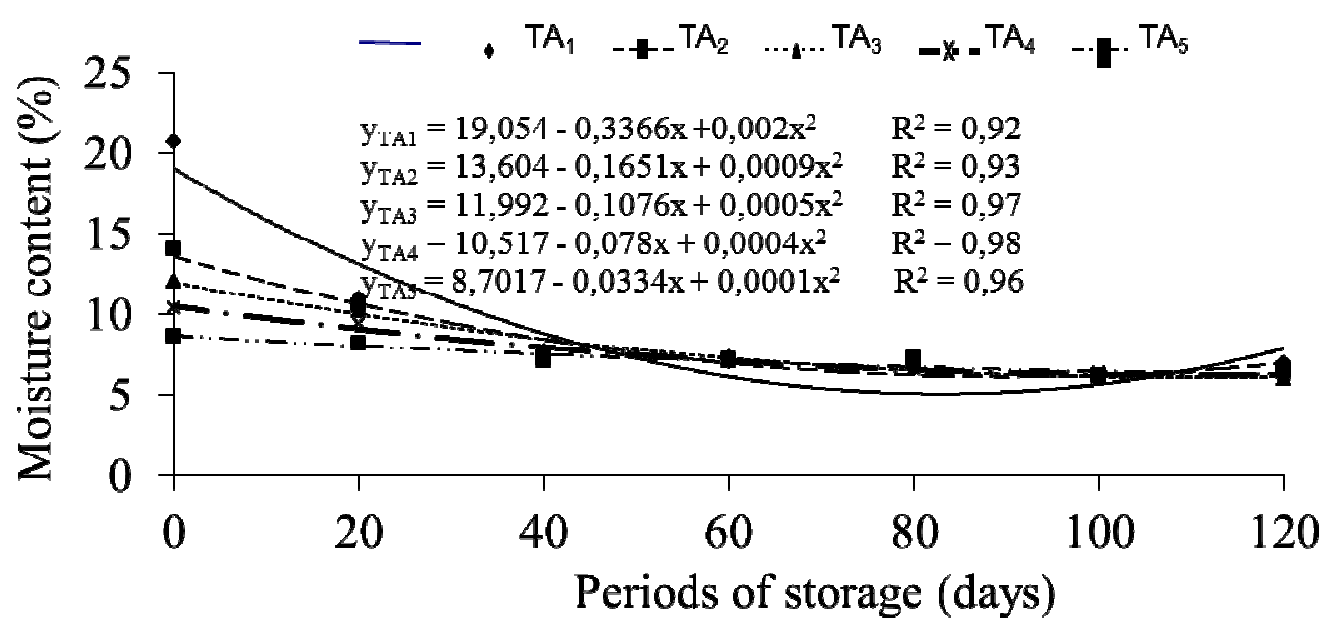

Figure 1. Water content of seeds of $C$. fairchildiana stored for different periods. TA1 $=19.05$, TA2 $=13.60$, TA3 $=11.99$, TA $4=10.51$ and TA $5=8.70$. 

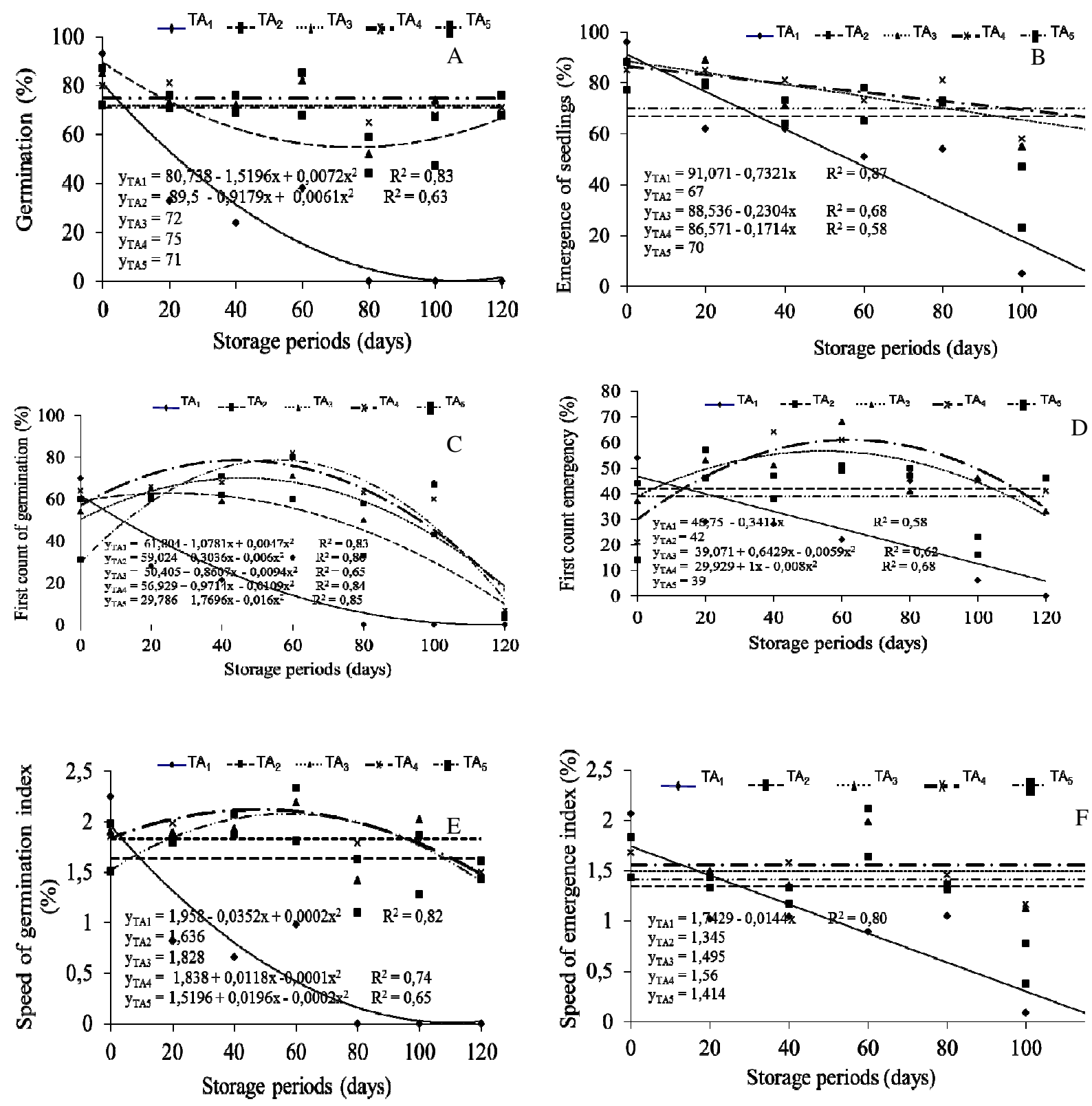

Figure 2. (A) seed germination, seedling emergence (B), first count of germination (C) and (D) seedling emergence, germination speed index (E) seed and seedling emergence (F) C. fairchildiana in seed storage function with different levels of water. $\mathrm{TA}_{1}=19,05, \mathrm{TA}_{2}=13,60, \mathrm{TA}_{3}=11,99, \mathrm{TA}_{4}=10,51 \mathrm{e} \mathrm{TA}_{5}=8,70$.

The germination speed index (IVG) decreased gradually over periods of storage, when the seeds were stored with the water content of $19.05 \%\left(\mathrm{TA}_{1}\right)$, the behavior was similar to verified. The data on the storage of seeds with water content of $13.60\left(\mathrm{TA}_{2}\right)$ and $11.99 \%\left(\mathrm{TA}_{3}\right)$ does not set the polynomial regression models, having an average of 1.64 and 1.83, respectively, while for the seeds stored with water levels $10.51\left(\mathrm{TA}_{4}\right)$ and $8.70 \%$ $\left(\mathrm{TA}_{5}\right)$ quadratic effect of data whose highest rates
(2.18 and 1.99) were observed to 59 and 49 days of storage respectively (Figure $2 \mathrm{E}$ ).

With respect to emergency speed index of seedlings of $C$. fairchildiana accented reductions occurred when the seeds were stored with water content of $19.05\left(\mathrm{TA}_{1}\right)$, while for the remaining water levels data sets the polynomial regression models, whose average values were $(1.34,1.49$, and 1.561 .41$)$, respectively (Figure $2 \mathrm{~F}$ ).

The permeability of the packaging combined with low relative humidity of the storage 
environment has contributed to reducing the moisture of seeds of Clitoria fairchildiana, so that the knowledge of the water content of the seeds is essential to determine appropriate conditions for storage (WARHM, 1996), being that the packaging and the environment are important factors in seed conservation (MARCOS FILHO, 2005).

When evaluating the physiological quality of seeds of Tabebuia chrysotricha (Mart. ex a. DC.) stored, Martins et al. (2009) found that extreme levels of water (21.1 and $8.5 \%$ ) caused immediate negative effects.

However, in seeds of Tabebuia impetiginosa Mart Martins et al. (2012a) found that the seeds with water levels of $12.5 ; 8.4$ and $4.2 \%$ were best preserved the vigor, determined by the emergency, emergency speed index and length of the aerial part of seedlings of ipê-roxo (Tabebuia impetiginosa
Mart.) from stored seeds with different water contents $(15 ; 6 ; 11.5 ; 4.3 \%)$ and 8.1 for 120 days was not reduced (MARTINS et al., 2012b).

For the root length of seedlings of $C$. fairchildiana from germination test and originated from seeds stored with $19.05 \%$ water content $\left(\mathrm{TA}_{1}\right)$ drastic reductions after 20 days of storage; for the seeds stored with $13.60 \%$ humidity $\left(\mathrm{TA}_{2}\right)$ there was across-the-board reduction depending on the length of time in storage. In seedlings from seeds with water content of $11.99 \%\left(\mathrm{TA}_{3}\right)$ to 40 days of storage was obtained the maximum length of root $(8.49 \mathrm{~cm})$, whereas those stored with the water content of $10.51 \%\left(\mathrm{TA}_{4}\right)$, the largest value $(8.68 \mathrm{~cm})$ was verified to 33 days and, for seedlings from seeds stored with water content of $8.70\left(\mathrm{TA}_{5}\right)$ at 49 days of storage was the greatest lengths $(7.36 \mathrm{~cm})$ of the root (Figure 3A).
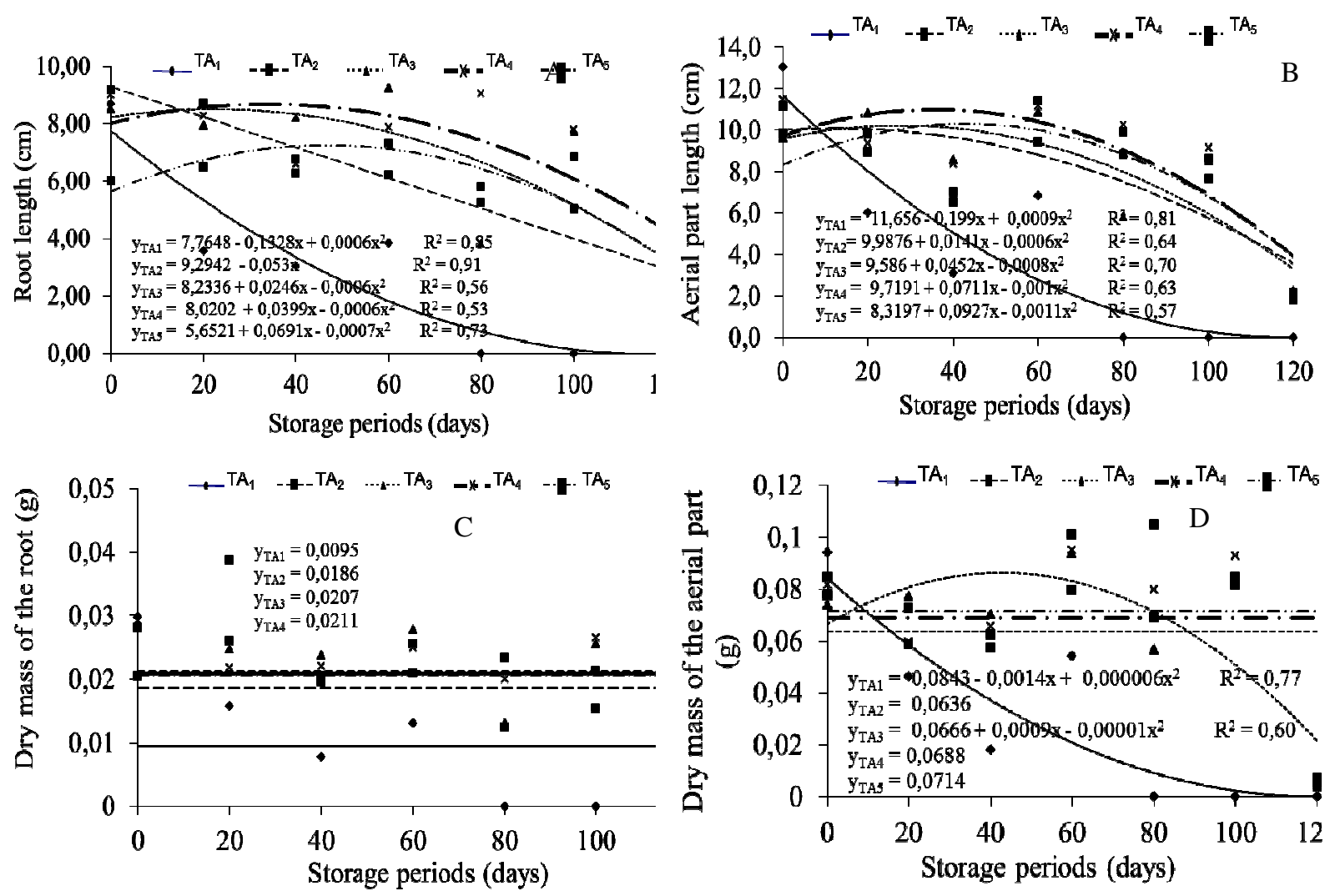

Figura 3. Length and dry mass of seedlings of $C$. fairchildiana germination test depending on the store. $\mathrm{TA}_{1}=19,05, \mathrm{TA}_{2}=13,60, \mathrm{TA}_{3}=11,99, \mathrm{TA}_{4}=10,51 \mathrm{e} \mathrm{TA}_{5}=8,70$.

The length of the aerial part of seedlings of C. fairchildiana decreased significantly when the seeds were stored with $19.05 \%$ humidity $\left(\mathrm{TA}_{1}\right)$, while those stored with the water content of $13.60 \%$ $\left(\mathrm{TA}_{2}\right)$ originated from seedlings with maximum length (10.07 inches) after 11 days of storage. For the seeds with water content of $11.99 \%\left(\mathrm{TA}_{3}\right)$ produced seedlings with higher lengths $(10.22 \mathrm{~cm})$ to 28 days of storage; those with $10.51 \%$ water content $\left(\mathrm{TA}_{4}\right)$ quadratic effect of data, whose greatest length (10.98 inches) was obtained when these were stored for 35 days, the same quadratic behavior was observed for seed with $8.70 \%$ water content $\left(\mathrm{TA}_{5}\right)$ where the seeds stored for 42 days 
originated with larger seedlings lengths $(10.27 \mathrm{~cm})$ (Figure 3B).

Analyzing the data of dry mass of roots of seedlings of $C$. fairchildiana (Figure 3C) it was found that there was no significant effect of the treatments, with average values of $0.0095 ; 0.0186$; $0.0207 ; 0.0211 ; 0,0209 \mathrm{~g}$, corresponding to the water content of $19.05 ; 13.60 ; 11.99 ; 10.51$ and $8.70 \%\left(\mathrm{TA}_{1}, \mathrm{TA}_{2}, \mathrm{TA}_{3}, \mathrm{TA}_{4}, \mathrm{TA}_{5}\right.$ and respectively). The dry matter content of the shoot of seedlings from seeds stored with $19.05 \%$ water content $\left(\mathrm{TA}_{1}\right)$ reduced significantly as it prolonged the period of storage in seedlings from seeds stored with the water content of $11.99 \%\left(\mathrm{TA}_{3}\right)$ the highest dry matter content $(0,09 \mathrm{~g})$ was registered with 120 days of storage. The data of aboveground dry weight of seedlings originating from seeds stored with water levels of $13.60 ; 10.51$ and $8.70 \%\left(\mathrm{TA}_{3}, \mathrm{TA}_{4}\right.$ and $\mathrm{TA}_{5}$ respectively) do not fit the regression models, with average values of $0.0636 ; 0.06880,0714 \mathrm{~g}$, respectively (Figure 3D).
By the data of the root length of seedlings of Clitoria fairchildiana from emergency test (Figure 4A) can be observed only for the seeds stored with water levels of 19.05 and $8.70 \%\left(\mathrm{TA}_{1}\right.$ and $\left.\mathrm{TA}_{5}\right)$ there was quadratic effect, whose greatest lengths $(10.26$ and $10,58 \mathrm{~cm})$ were obtained at the age of 48 and 64 days of storage, respectively. For the seeds that were stored with water levels 13.60; 11.99 and $10.51 \%\left(\mathrm{TA}_{2}, \mathrm{TA}_{3}\right.$ and $\mathrm{TA}_{4}$, respectively) the data is not adjusted the polynomial regression models, obtaining 8.62 averages; 10.1 and 9.73, respectively, indicating that the water levels on seeds and storage periods did not influence this variable. The length of the shoots of seedlings from seeds stored with water levels of $13.60 ; 11.99$ and $8.70 \%\left(\mathrm{TA}_{2}, \mathrm{TA}_{3}\right.$ and $\left.\mathrm{TA}_{5}\right)$ varied, with average values of $11.35 ; 11.5$ and 11.57 inches, respectively, while for those stored with water levels 19.05 and $10.51 \%\left(\mathrm{TA}_{1}\right.$ and $\left.\mathrm{TA}_{4}\right)$ reductions in the length of the aerial part of their seedlings from the 20 days of storage (Figure 4B).
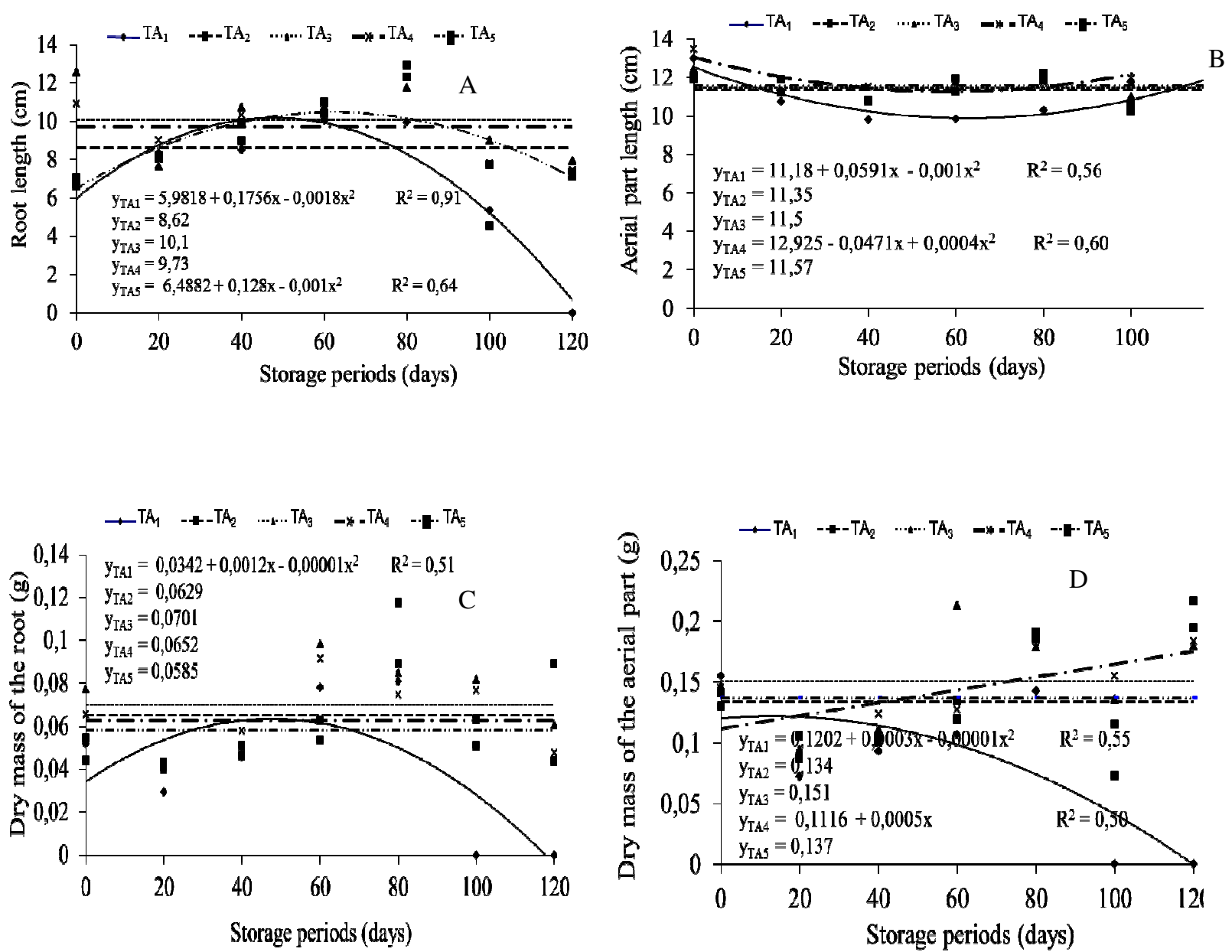

Figure 4. Length and dry mass of seedlings of $C$. fairchildiana from emergency test depending on the store. $\mathrm{TA}_{1}=19,05, \mathrm{TA}_{2}=13,60, \mathrm{TA}_{3}=11,99, \mathrm{TA}_{4}=10,51$ e $\mathrm{TA}_{5}=8,70$. 
The greatest dry matter content $(0,07 \mathrm{~g})$ the roots of seedlings originating from seeds stored with $19.05 \%$ humidity $\left(\mathrm{TA}_{1}\right)$ occurred to 60 days; seeds stored with water levels of $13.60 ; 11.99 ; 10.51$ and $8.70 \%\left(\mathrm{TA}_{2} \mathrm{TA}_{3} \mathrm{TA}_{4} \mathrm{TA}_{5}\right.$, and, respectively) there were no differences between treatments, obtaining 0.0629 averages; $0.0701 ; 0.0652$ and $0.0585 \mathrm{~g}$ respectively. How to dry pasta from the shoot of seedlings from seeds stored with $19.05 \%$ water content $\left(\mathrm{TA}_{1}\right)$ the same decreased with increased storage periods, while those from seeds with $10.51 \%$ water content $\left(\mathrm{TA}_{4}\right)$ linear positive effect depending on the water contents of seeds. The seeds stored with humidity of $13.60 ; 11.99$ and $8.70 \%$ $\left(\mathrm{TA}_{2}, \mathrm{TA}_{3}\right.$ and $\mathrm{TA}_{5}$, respectively) originated seedlings whose dry mass was not influenced by the storage periods, with average values of 0.134; $0.151 ; 0.137 \mathrm{~g}$, respectively (Figure 4D). The greatest dry matter content of seedlings quixabeira's shoot (Sideroxylon obtusifolium (Roem. \& Schult) Penn.) in the refrigerator environment was obtained when seeds wrapped in aluminum paper packing (SILVA et al., 2012).

\section{CONCLUSION}

The seeds of $C$. fairchildiana with water content $\left(\mathrm{TA}_{4}\right.$ 10.51) saved the physiological potential of seeds, up to 120 days of storage.

RESUMO: A espécie Clitoria fairchildinana, R. A. Howard pertencente à família Fabaceae, é uma arbórea ornamental de crescimento rápido, com potencial de utilização nos reflorestamentos heterogêneos destinados à reconstituição da vegetação e recuperação de áreas degradadas. O armazenamento é auxílio em programas de qualidade, que possibilita a conservação da qualidade das sementes, contudo, o teor de água das mesmas é um fator crucial na sua preservação, se elevado, pode provocar deterioração e morte das sementes no armazenadas. Objetivou-se avaliar a germinação e o vigor das sementes de C. fairchildiana, quando armazenadas com diferentes teores de água. Para isto realizou-se um experimento em delineamento inteiramente casualizado em um fatorial 5 x 7 (teores de água e períodos de armazenamento). Antes do armazenamento as sementes foram submetidas à secagem em estufa na temperatura de $40^{\circ} \mathrm{C}$ durante 24 horas, para a obtenção dos diferentes teores de água $\left(\mathrm{TA}_{1}, \mathrm{TA}_{2}, \mathrm{TA}_{3}, \mathrm{TA}_{4}\right.$ e $\left.\mathrm{TA}_{5}\right)$ correspondentes aos períodos de secagem de 0,6,12, 18 e 24, respectivamente. Para cada período de secagem foi determinado o teor de água das sementes e estas foram armazenadas em geladeira por 120 dias com avaliações nos períodos de $(0,20,40,60,80,100$ e 120) dias. Após cada intervalo de armazenamento as sementes foram submetidas às seguintes avaliações: (determinação do teor de água, germinação e emergência, primeira contagem de germinação e emergência e índice de velocidade de germinação e emergência, comprimento e massa seca de plântulas). A redução do teor de água das sementes $C$. fairchildiana para $10,5 \%$ e $8,7 \%\left(\mathrm{TA}_{4}\right.$ e $\left.\mathrm{TA}_{5}\right)$, respectivamente, resultou em uma maior conservação das mesmas durante $\mathrm{o}$ armazenamento. As sementes da referida espécie tem comportamento ortodoxo e suporta a secagem por 24 horas quando as sementes atinge o teor de água em torno de $8 \%$.

PALAVRAS-CHAVE: Longevidade. Vigor. Espécie florestal.

\section{REFERENCES}

ALVES, E. U.; SILVA, K. B.; BRUNO, R. L. A.; ALVES, A. U.; CARDOSO, E. A.; GONÇALVES, E. P.; BRAZ M. S. S. Comportamento fisiológico de sementes de pitombeira Talisia esculenta (A. ST. Hil) Radlk submetidas à desidratação. Revista Brasileira Fruticultura, Jaboticabal, v. 30, n. 2, p. 509-516, 2008.

BRASIL. Ministério da Agricultura, Pecuária e Abastecimento. Regras para análise de sementes. Secretaria de Defesa Agropecuária. Brasília: MAPA/ACS, 2009. 395p.

CARVALHO, N. M.; NAKAGAWA, J. Sementes: ciência, tecnologia e produção. 5.ed. Jaboticabal: FUNEP, 2012. 590p.

CARVALHO, L. R.; SILVA, E. A. A.; DAVIDE, A. C. Classificação de sementes florestais quanto ao comportamento no armazenamento. Revista Brasileira de Sementes, Pelotas, v. 28, n. 2, p. 15-25, 2006.

CARNEIRO, J. G. A.; AGUIAR, I. B. Armazenamento de sementes. In: AGUIAR, I. B.; PIÑA-RODRIGUES, F. C. M.; FIGLIOLIA, M. B. Sementes florestais tropicais. Brasília: ABRATES, 1993. p. 333-350. 
LORENZI, H. Árvores brasileiras: Manual de identificação e cultivo de plantas arbóreas nativas do Brasil. 2.ed. Nova Odessa: Plantarum, 2009. 368p.

MAGUIRE, J. D. Speed of germination aid in selection and evaluation for seeding emergence and vigor. Crop Science, Madison, v. 2, n. 2, p. 76-177, 1962.

MARTINS, L.; LAGO, A. A.; ANDRADE, A. C. S. Teor de água, temperatura do ambiente e conservação de sementes de ipê-roxo. Revista Árvore, Viçosa, v. 36, n. 2, p. 203-210, 2012 a.

MARTINS, L.; LAGO, A. A.; CÍCERO, S. M. Conservação de sementes de ipê-roxo. Revista Brasileira de Engenharia Agrícola e Ambiental, Campina Grande, v. 16, n. 1, p. 108-112, 2012 b.

MARTINS, L.; LAGO, A. A.; SALES, W. R. M. Conservação de sementes de ipê-amarelo Tabebuia chrysotricha (Mart. ex A. DC.) Standl.) em função do teor de água das sementes e da temperatura do armazenamento. Revista Brasileira de Sementes, Londrina, v. 31, n. 2, p. 86-95, 2009.

MARCOS FILHO, J. Fisiologia de sementes de plantas cultivadas. Piracicaba: FEALQ, 2005. 495p.

SILVA, K. B.; ALVES, E. U.; OLIVEIRA, A. N. P. Avaliação de sementes de Sideroxylon obtusifolium (Roem. \& Schult.) T. D. Penn. sob diferentes condições de armazenamento. Revista de Ciências AgroAmbientais, Alta Floresta, v. 10, n. 1, p. 69-80, 2012.

ROBERTS, E. H. Predicting the storage life of seeds. Seed Science and Technology, Zürich, v. 1, n. 4, p. 499$514,1973$.

WARHM, E. J. A. Comparison of packing materials for seed with particular reference to humid environments. Seed Science and Technology, Zürich, v. 14, n. 1, p. 191-211, 1996. 